\title{
On the functionality of the N-terminal domain in xylanase 10A from Ruminococcus albus 8
}

\author{
Alem Storani, Sergio A. Guerrero, Alberto A. Iglesias* \\ Laboratorio de Enzimología Molecular, Instituto de Agrobiotecnología del Litoral (CONICET - UNL). Facultad de Bioquímica y Ciencias Biológicas, Universidad Nacional \\ del Litoral, 3000, Santa Fe, Argentina
}

\section{A R T I C L E I N F O}

\section{Keywords:}

Carbohydrate binding module

Xylan

Adsorption

Ruminoccocus

\begin{abstract}
A B S T R A C T
We analyzed the structure to function relationships in Ruminococcus albus 8 xylanase 10A (RalXyn10A) finding that the N-terminus 34-amino acids sequence (N34) in the protein is particularly functional. We performed the recombinant wild type enzyme's characterization and that of the truncated mutant lacking the N34 extreme (Ral $\Delta$ N34Xyn10A). The truncated enzyme exhibited about half of the activity and reduced affinity for binding to insoluble saccharides. These suggest a (CBM)-like function for the N34 motif. Besides, RalXyn10A activity was diminished by redox agent dithiothreitol, a characteristic absent in Ral $\Delta$ N34Xyn10A. The N34 sequence exhibited a significant similarity with protein components of the ABC transporter of the bacterial membrane, and this motif is present in other proteins of R. albus 8. Data suggest that N34 would confer RalXyn10A the capacity to interact with polysaccharides and components of the cell membrane, enhancing the degradation of the substrate and uptake of the products by the bacterium.
\end{abstract}

\section{Introduction}

Lignocellulose constitutes the primary raw material for the production of secondgeneration biofuels $[1,2]$. The development of accurate technology for such bioenergy purposes has a critical limitation linked to the complex structure that makes lignocellulosic material recalcitrant to degradation. In this context, the search for more efficient enzymes with the ability to efficiently hydrolyze the polymeric biomass is a significant issue for biochemical studies. Xylans are the hemicellulose's main components being closely associated with cellulose fibrils by, together with lignin, covering the fiber surfaces [1-4]. In degradative biomass treatments, even low amounts of residual xylans can limit the extent and efficiency of the enzymatic hydrolysis of cellulose. The addition of xylanases can overcome this curtail, as such enzymes hydrolyze hemicellulose, releasing xylan from the substrates, thus improving the degradation of the polymeric material [3-9].

Xylans are polysaccharides made up of a linear backbone of $\beta-(1 \rightarrow 4)$ D-xylopyranosyl units with side branches at positions $2-\mathrm{O}$ and 3-O of $\alpha$-L-arabinofuranosyl, 4-O-methyl-glucopyranosyl uronic acid, and acetyl groups $[8,10]$. Endo $\beta-1,4-x y l a n a s e s$ cleave internal $\beta-1,4-$ glycosyl bonds in the xylans' main chain, giving rise xylooligosaccharides as products. As reported for cellulases [11-13], many xylanases exhibit a complex modular structure. This latter comprises a catalytic domain (CD), and a non-catalytic polypeptide fused to by either the $\mathrm{N}$ - or the C-terminus (or both) by flexible linkers rich in proline, threonine, and serine residues. The non-catalytic domain exerts a function as a carbohydrate-binding module (CBM) or as an enhancer of the enzyme thermostability [14-18]. Currently, 87 different families of CBMs have been categorized based on amino acid sequence similarities (http://www.cazy.org) [14,19].

Ruminococcus albus 8 is widely known as one of the most active lignocellulolytic ruminal microorganisms. It can degrade cellulose and hemicellulose in forages such as alfalfa and grass hays. This bacterium produces a wide range of glycoside hydrolase $(\mathrm{GH})$ proteins, including enzymes that can degrade lignocellulose [20-23]. In this respect, different genes and protein products from $R$. albus 8 have been characterized as (i) cellulases Cel5G, Cel9B, Cel9C, and Cel48A); (ii) an extracellular $\alpha$-L-arabinofuranosidase [20]; and (iii) xylanase 11C [24]. Besides, the molecular cloning of the gene xynA from R. albus 7 allowed the production and biochemical study of the respective recombinant xylanase [21].

Moon et al. [22] reported biochemical analyses of the genome from

Abbreviations: 2ME, 2-mercaptoethanol; ABC, ATP-Binding Cassette; CBM, Carbohydrate binding module; DTT, Dithiothreitol; HEDS, 2-hydroxyethyldisulfide; MetGlcA-xylan, 4-O-methyl-D-glucurono-D-xylan; SBP, Substrate Binding Protein.

* Corresponding Author: Instituto de Agrobiotecnología del Litoral, CCT-Santa Fe. Colectora Ruta Nacional 168 Km 0, 3000, Santa Fe, Argentina.

E-mail address: iglesias@fbcb.unl.edu.ar (A.A. Iglesias). 
R. albus 8 with an emphasis on identifying enzymes that degrade the hemicellulose component of the plant cell wall. The authors identified five putative endoxylanases: ORF2725, ORF2882, ORF997, ORF1984, and ORF2008 and characterized the respective recombinant proteins. Based on amino acid sequences, the protein products of ORF2725 and ORF2882 belong to the GH10 family, and they were R. albus 8 Xyn10A and $\mathrm{Xyn} 10 \mathrm{~B}$, respectively. According to this study, the structure of Xyn10B comprises a GH10 domain and three carbohydrate-binding modules (CBMs), whereas Xyn10A would be a protein with only endoxylanase ability. We performed a more detailed analysis to find that Xyn10A (377 amino acids) comprises not only a GH10 catalytic module but also an N-terminal domain of 34-amino acids (N34) with no assigned putative function. This latter raised the question about a possible functionality for such an N-term of Xyn10A.

Herein, we report the molecular cloning of the ralxyn10A gene to produce and characterize the entire recombinant protein and the N34 truncated form. Results support differences between the full-length protein and the shortened form of RalXyn10A in the efficiency and redox dependence for hydrolyzing polysaccharides, thus identifying the $\mathrm{N}$-term as a new domain with CBM and regulatory functions.

\section{Materials y methods}

\subsection{Bacteria, plasmids, and primers}

Escherichia coli Top $10 \mathrm{~F}^{\prime}$ and E. coli BL21 (DE3) (Invitrogen) served as hosts for cloning purposes and expression of the genes cloned in the pETDuet vector (Novagen). DNA manipulations and E. coli cultures, as well as transformations, were performed according to standard protocols [25]. Table S1 details all the primers (obtained from GenBiotech) utilized in this work.

\subsection{Endoxylanase constructs}

We designed a gene (ralxyn10A) coding for endoxylanase RalXyn10A for de novo synthesis (BIO BASIC INC) based on information from the R. albus 8 partial genome sequence (GenBank accession no: AEE64767.1). The gene design considered the E. coli codon usage to optimize the heterologous production of the recombinant protein. BamHI and HindIII restriction sites flanked the constructed gene for its afterward cloning and expression purposes. The plasmid pUC57/ral$x y n 10 A$, containing the synthetic gene, was digested with BamHI and HindIII. The resulting products were separated electrophoretically in $1 \%$ $(\mathrm{w} / \mathrm{v})$ agarose gel and purified using a Wizard SV gel \& PCR Clean-Up kit (Promega). The digested gene was subcloned into pETDuet (previously digested with the same enzymes) to obtain the construction pETDuet/ ralxyn10A yielding a fusion protein having an N-terminal His-tag. This construct then served to transform E. coli BL21 (DE3) competent cells.

The DNA fragment encoding only for the GH10 catalytic domain was amplified by PCR from the plasmid pUC57/ralxyn10A to produce the truncated mutant protein lacking the N34 domain. For this subcloning, we used the primers Xyn10A $\Delta$ NFow and Xyn10ARev, respectively (Table S1), containing BamHI and HindIII restriction sites for cloning the PCR fragments into the pETDuet expression vector. A similar approach was useful to build the chimeric protein $\mathrm{N} 34-\mathrm{TbrCglT}$, which is composed of the N34 domain from RalXyn10A (N34-) fused to the Nterm of the $\beta$-glucosidase from Thermoanaerobacter brockii (TbrCglT) [26]. Thus, the DNA encoding for the N-terminal of RalXyn10A was amplified by PCR from [pUC57/ralxyn10A] with primers NCBMXyn10AFow and NCBMXyn10ARev containing BamHI and NotI restriction sites for later insertion into pETDuet vector. The pETDuet vector containing the first 102 nucleotides (N34) of ralxyn10A was digested with the corresponding restriction enzymes, and the tbrcglt gene was then subcloned to obtain the construction pETDuet/n34-tbcglt. Both constructs were used to transform $E$. coli BL21 (DE3) competent cells.

For amplification by PCR, samples contained $0.1 \mathrm{ng}$ of pUC57/
ralxyn10A, $100 \mathrm{pmol}$ of each primer, and $2.5 \mathrm{U}$ of Taq DNA polymerase (Fermentas) were incubated under the following conditions: $5 \mathrm{~min}$ at $95^{\circ} \mathrm{C}, 30$ cycles of $1 \mathrm{~min}$ at $95^{\circ} \mathrm{C}, 30 \mathrm{~s}$ at $55^{\circ} \mathrm{C}$ and $1 \mathrm{~min} 15 \mathrm{~s}$ at $72{ }^{\circ} \mathrm{C}$, followed by $10 \mathrm{~min}$ at $72{ }^{\circ} \mathrm{C}$. After cloning the amplified DNA fragments into the pGEM-T Easy vector (Promega), the resulting constructions were used to transform $E$. coli TOP10 cells. Automated sequencing analysis (Macrogen) confirmed the correctness of sequences of the amplified genes.

\subsection{Site-directed mutagenesis}

The QuikChange II site-directed mutagenesis kit (Agilent) was the experimental tool to introduce C5S, C78S, and C111S mutations in the ralxyn10A gene. We used pairs of complementary primers (having the particular mutation in the middle of the sequence) C5SXyn10AFow plus C5SXyn10ARev, or C78SXyn10AFow plus C78SXyn10ARev, or C111SXyn10AFow plus C111SXyn10ARev. The mutation medium contained the respective pair of primers, plus $10 \mathrm{ng}$ of the [pETDuet/ralxyn10A] plasmid as the template, and PfuUltra high-fidelity DNA polymerase. PCR conditions consisted of 16 cycles at $95^{\circ} \mathrm{C}$ for $1 \mathrm{~min}$, $55^{\circ} \mathrm{C}$ for $1 \mathrm{~min}$, and $68^{\circ} \mathrm{C}$ for $13 \mathrm{~min}$. After treatment with $D p n$ I endonuclease, the product served to transform $E$. coli Top $10 \mathrm{~F}$ ' cells for plasmid propagation and mutant selection. The entire sequencing of the double-strand DNA verified the introduction of the desired mutations.

\subsection{Protein expression and purification}

E. coli BL21(DE3) cells transformed with both [pETDuet/ralxyn10A], [pETDuet/ralsn34xyn10A] and [pETDuet/n34-tbcglt] were grown at $37^{\circ} \mathrm{C}$ in LB medium supplemented with $50 \mu \mathrm{g} \cdot \mathrm{ml}^{-1}$ ampicillin until reach an OD600 0.6. Protein expression was induced with IPTG $(0.2 \mathrm{mM})$ at $24^{\circ} \mathrm{C}$ for $16 \mathrm{~h}$. Cells were harvested by centrifuging $15 \mathrm{~min}$ at $5,000 \times \mathrm{g}$ and $4{ }^{\circ} \mathrm{C}$ and the pellet suspended in $5 \mathrm{~mL}$ of buffer $\mathrm{A}$ [25 mM Tris- $\mathrm{HCl} \mathrm{pH} \mathrm{8.0,300} \mathrm{mM} \mathrm{NaCl,} 5 \%$ (v/v) glycerol, $10 \mathrm{mM}$ imidazole] per gram of cells. Cells were disrupted by sonication on ice and centrifuged $20 \mathrm{~min}$ at $16,000 \times \mathrm{g}$ and $4^{\circ} \mathrm{C}$. RalXyn10A, Ral $\Delta \mathrm{N} 34-$ Xyn10A, N34-TbrCglT, and RalXyn10A mutants (C5S, C78S, and C111S) were purified by ion metal affinity chromatography (IMAC), using $1 \mathrm{~mL}$ HisTrap $^{\mathrm{TM}}$ HP columns (GE Healthcare) followed by a gel filtration chromatography Superdex G-200. Briefly, supernatants were loaded onto previously equilibrated $\mathrm{Ni}^{2+}$ charged columns. After extensively washing with buffer A, samples were eluted with a $10-300 \mathrm{mM}$ imidazole linear-gradient ( 50 column volumes). Active fractions were pooled and loaded onto a Superdex G-200 column and eluted with buffer A without imidazole. All proteins were stable for at least three months when stored at $-80^{\circ} \mathrm{C}$ under these conditions.

\subsection{Protein methods}

Protein concentration was determined by the Bradford [27] procedure using bovine serum albumin as a standard. Sodium dodecyl sulfate-polyacrylamide gel electrophoresis (SDS-PAGE) (in the presence or absence of reducing agent) was performed according to Laemmli [28]. Polyacrylamide monomer concentration was $10 \%(w / v)$ for the separating gel and $4 \%(\mathrm{w} / \mathrm{v})$ for the stacking gel. Coomassie Brilliant Blue was used for protein staining.

\subsection{Molecular mass determination}

The quaternary structure of the purified RalXyn10A and Ral $\Delta$ N34Xyn10A was analyzed by gel filtration chromatography. The sample was loaded in a Superdex Tricorn 10/300 column (GE Healthcare) in buffer $\mathrm{G}$ (50 mM HEPES-NaOH pH 8.0, $100 \mathrm{mM} \mathrm{NaCl}$, and $0.1 \mathrm{mM}$ EDTA). The molecular mass was calculated using a calibration plot constructed with protein standards from GE Healthcare, including thyroglobulin (669 kDa), ferritin (440 kDa), aldolase (158 kDa), conalbumin (75 kDa), 
ovalbumin (44 kDa), carbonic anhydrase (29 kDa), and ribonuclease A $(13.7 \mathrm{kDa})$. The column void volume was measured using a dextran blue loading solution (Promega).

\subsection{Enzymatic assays}

The standard assay of xylanase activity was performed by using 4-Omethyl-D-glucurono-D-xylan (MetGlcA-xylan, Sigma-Aldrich) as the substrate. Measurements conditions were $10 \mathrm{~min}$ incubation at $40^{\circ} \mathrm{C}$ in buffer sodium acetate $100 \mathrm{mM}, \mathrm{pH} 6.0$, with proper enzyme dilution. Reducing sugars released from MetGlcA-xylan were determined with the Somogyi-Nelson method [29,30]. The substrate consumption was maintained below $10 \%$ as a control to assure the proper determination of initial velocity $\left(v_{0}\right)$. One unit (U) of enzyme activity is equal to $1 \mu \mathrm{mol}$ of xylose equivalent released per minute under the respective assay conditions specified above.

The optimum temperature of RalXyn10A and Ral $\Delta$ N34Xyn10A was determined assaying the standard activity except that the temperature varied in the range $4-70^{\circ} \mathrm{C}$. Optimum $\mathrm{pH}$ was measured by assaying enzyme activity at $40^{\circ} \mathrm{C}$ in buffers citrate ( $\mathrm{pH} 3-5$ ), acetate (pH 5-7), or phosphate ( $\mathrm{pH}$ 5-9). The thermostability and pH stability of the purified enzymes were measured by incubating them for $1 \mathrm{~h}$ at various temperatures $\left(4-70^{\circ} \mathrm{C}\right)$ and $\mathrm{pH} 6.0$, or at variable $\mathrm{pHs}$ (in the range 4-9) at $4{ }^{\circ} \mathrm{C}$. After incubation, the residual enzyme activity was assayed under the standard assay conditions.

\subsection{Binding to carbohydrate assays}

Binding of RalXyn10A, RalsN34Xyn10A, N34-TbrCglT, and TbrCglT to insoluble polysaccharides was determined as follows: the enzyme $(0.1 \mathrm{mg})$ was mixed with polymer $(5 \mathrm{mg})$ in $0.5 \mathrm{~mL}$ of $100 \mathrm{mM}$ sodium acetate buffer ( $\mathrm{pH} 6.0)$ and incubated at $25^{\circ} \mathrm{C}$ for $1 \mathrm{~h}$ with stirring $(1500$ $x g$ ). After centrifugation at $3000 \times g$ for $5 \mathrm{~min}$, the supernatant was separated, and the unbound enzyme quantified by the Bradford procedure [27]. The insoluble polysaccharide was washed thrice with sodium acetate buffer, and then bound protein was eluted with sodium dodecyl sulfate (SDS) $10 \%(\mathrm{w} / \mathrm{v})$ at $90^{\circ} \mathrm{C}$ for $10 \mathrm{~min}$ and analyzed by SDS-polyacrylamide gel electrophoresis (SDSPAGE). The polysaccharides tested were pure cellulose, filter paper, pine sawdust, chitin, and insoluble arabinoxylan. To analyze the effect of a reduction agent on cysteinyl mutant variants of the enzyme, prior incubation with the insoluble polysaccharide, the respective enzyme was incubated with DTT $(3 \mathrm{mM})$ in Buffer B for $20 \mathrm{~min}$ at $25^{\circ} \mathrm{C}$. After treatment, we carried out binding assays as described above.

\subsection{Oxidation and reduction assays}

Oxidation and reduction assays were carried out by incubating the enzymes $(30 \mu \mathrm{M})$ at $25^{\circ} \mathrm{C}$ in buffer B for $20 \mathrm{~min}$ with 2-ME, DTT, diamide, or $\mathrm{H}_{2} \mathrm{O}_{2}$ in different concentrations $(0-30 \mathrm{mM})$. After treatment, the sample was assayed for activity. Experimental data were plotted as the percentage of remaining activity versus reagent concentration, taken as the reference control the enzyme incubated in the absence of any redox reagent. When necessary, redox reagent remaining after treatment was eliminated by desalting the samples on a Bio-Gel P6 (Bio-Rad) mini-column. Experimental points determined in redox modification studies are means of at least three measurements reproducible within $\pm 10 \%$.

\subsection{Determination of the midpoint reduction potential}

The $E_{m}$ of a protein is the reduction potential at which the concentration of its oxidized and reduced forms are equal [31]. The $\mathrm{E}_{\mathrm{m}}$ values of RalXyn10A and its mutants were determined by redox titration with 2ME-HEDS, the reduced and oxidized species of $\beta$-mercaptoethanol, respectively, which interexchange according to the reaction: $2 \mathrm{ME} \leftrightarrow$
$2 \mathrm{H}++2 \mathrm{e}-+$ HEDS. Different reduction potential values were obtained, varying the relative concentration fixed at $25 \mathrm{mM}$, with the addition of $50 \mathrm{mM}$ HEPES $\mathrm{pH}$ 8.0. The $\mathrm{E}_{\mathrm{h}}$ values were calculated by using the Nernst equation applied to the reduction reaction stated above: $E_{h}=E_{m, 8.0}$ $-\mathrm{RT} / \mathrm{nF}$ Ln ([2ME] ${ }^{2} /\left[\right.$ HEDS]), where $\mathrm{E}_{\mathrm{m}, 8.0}$ is the $\mathrm{E}_{\mathrm{m}}$ for $2 \mathrm{ME} / \mathrm{HEDS}$ at $\mathrm{pH} 8.0(-0.319 \mathrm{~V})$ [32], $\mathrm{R}$ is the universal gas constant $(8.314 \mathrm{~J}$ $\left.\mathrm{K}^{-1} \mathrm{~mol}^{-1}\right), \mathrm{T}$ is the absolute temperature $(303 \mathrm{~K}), \mathrm{n}$ is the number of moles of electrons transferred in the reaction, and $\mathrm{F}$ is the Faraday constant $\left(96.485 \mathrm{~kJ} \mathrm{~mol}^{-1} \mathrm{~V}^{-1}\right)$ [31].

The different enzymes $(5 \mu \mathrm{M})$ were incubated for $1 \mathrm{~h}$ at room temperature in various redox buffers and then assayed for activity under standard conditions. Values of enzyme activity were plotted versus $E_{\mathrm{h}}$ and fitted to the Nernst equation using the program Origin 8.0 to calculate the $E_{\mathrm{m}}$.

\subsection{Sequences alignment and molecular modeling}

Multiple sequence alignments were performed using ClustalW [33], and similarity search between sequences was used to predict protein domains functions. Alignments were displayed using ESPript3.0 (http ://espript.ibcp.fr/ESPript/ESPript/) [34]. The search for suitable template models was performed with the template identification tool of the Swiss Model Workspace [35]. The deduced crystal structure model of endo-beta-1,4-D-xylanase10B from Clostridium thermocellum (PDB ID: 2W5F) showed the best identity to RalXyn10A [36], after which was used as a template for homology modeling. Sequences of the selected template were aligned using the program HHBlits [37], and ten homology models of RalXyn10A were obtained using the software Modeller $9.15[38,39]$. Special care was taken to avoid any gap inside of secondary structure elements. To establish the best model, we took into account the more top global score of verify3D [40], the higher z DOPE [41], and the QMEAN [42] potential values. Secondary structure prediction of the complete protein sequence (RalXyn10A) was made by Jpred4 [43]. The building of the structure model of N34 motif was made by I-TASSER $[44,45]$ server using ten threading templates (PDB ID: 1 PS M; 4H2S; 1AA7; 1Y04; 1J51; 1DMC; 3CWR; 5OHG; 21NK; 1ZNF). The model was selected by the higher C-score [45] and analyzed for global structure quality score with verify3D [40], the QMEAN [42] potential values.

\section{Results}

\subsection{Characterization of the kinetic and physicochemical properties of recombinant RalXyn10A and RalsN34Xyn10A from R. albus 8}

Two endo-xylanases assigned to the GH10 family (Xyn10A and Xyn10B) are identified from the genome of $R$. albus 8 (GenBank accession no. ADKM00000000.2). Both proteins, recognized in the proteome project ID UP000004259, were characterized by Moon et al. [22] in a study based on the functional analysis of structural domains. The authors considered that Xyn10A was a protein primarily comprising a xylanase domain, whereas Xyn10B exhibited a higher structural complexity by also having three functional CBMs. We performed more detailed scrutiny of the structure of RalXyn10A (Fig. 1), revisiting the $\mathrm{N}$-term of the protein, which is out of the primary domain and was considered non-functional. Fig. S1 illustrates an alignment of the amino acid sequence of RalXyn10A (377 amino acids) and Xyn10B (811 amino acids), where it is clear the presence of the xylanase domain in both proteins. In the alignment, the GH10 catalytic domain from each protein shares $42 \%$ similarity ( $31 \%$ identity) with the other one. Xyn10B also possesses three structural areas with conserved sequences of functional CBMs (of the type CBM4 9, CBM22, and CBM37).

Flanking the GH10 domain, RalXyn10A has a 34 amino acid chain at the N-term (Fig. 1). Analyzing the sequence structure of the N34 extension, we sought for comparison with different CBMs already reported. As shown in Fig. S2, a maximal similarity of $23 \%$ (15\% identity) 


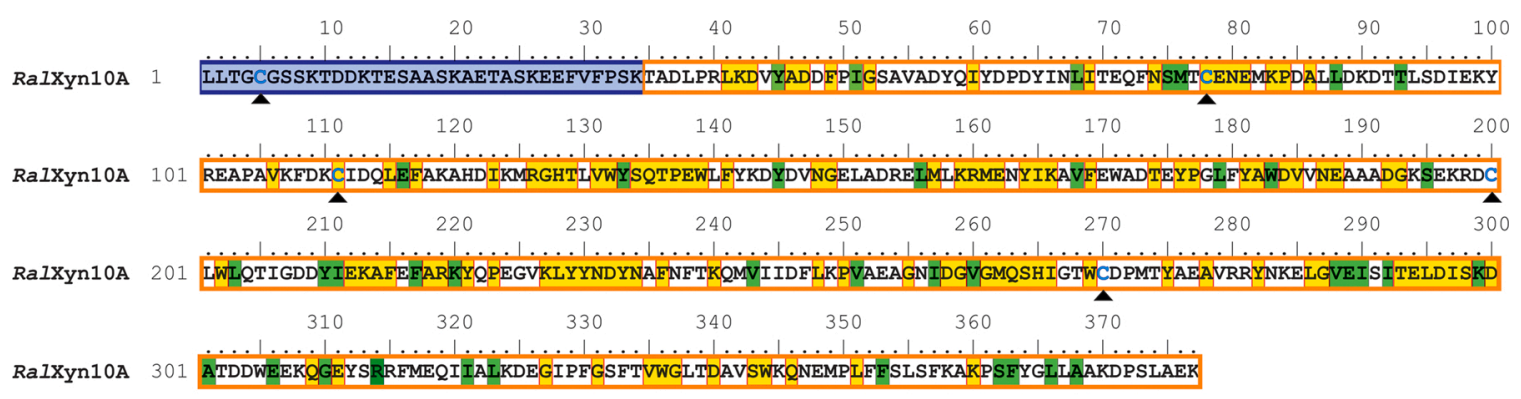

$\square$ N34 domain $\square$ Conserved amino acids

$\square$ GH10 domain $\square$ semi-conserved amino acids

- Cystein residues

Fig. 1. Amino acid sequence of a GH10 xylanase from Ruminococcus albus 8 (RalXyn10A). Strictly conserved amino acids in GH10 xylanases are colored in yellow and semi-conserved amino acids in green. N34 motif and GH10 catalytic modules are highlighted in blue and orange boxes, respectively. The extracellular signal peptide sequence (13 amino acids) predicted by the SignalP server was removed from the sequence display (For interpretation of the references to colour in this figure legend, the reader is referred to the web version of this article.).

was found concerning CBM37a from the Cel5G protein of $R$. albus 8 [22, 24]. Alignment with other CBM sequences indicated low levels of similarity, with values between $7 \%$ and $20 \%$ (identity between $3 \%$ and 10 $\%$ ). The grouping sequences respect to the multiple binding functional domains confirmed the absence of identity. These results made suppose that the $\mathrm{N}$-term lacks CBM functionality in the previous characterization of RalXyn10A [22]. However, it would be valuable to explore the issue further, considering the currently limited identification of CBMs at the present and also the possible association with other roles like protein stability, catalysis, and regulation.

To advance in the search for the functionality (if any) of the N-term of RalXyn10A from $R$. albus 8, we designed a strategy to recombinantly produce two variants of the enzyme: the total 377 amino acids protein (RalXyn10A), and the truncated version lacking the 34 residues from the N-term (Ral $\Delta$ N34Xyn10A) (Fig. 1). Both forms of the enzyme contained a His-tag fused to the $\mathrm{N}$-term, which eased purification by $\mathrm{Ni}^{2+}$-affinity $\left(\mathrm{Ni}^{2+}\right.$-IDA) chromatography. Fig. 2 shows that the two recombinant proteins where produced and purified to a high electrophoretic degree. The molecular mass estimated for the entire and the truncated proteins from the SDS-PAGE migration agrees with the expected size of about $50 \mathrm{kDa}$ and $45 \mathrm{kDa}$, respectively (Fig. 2A). Besides, both proteins eluted from a size exclusion chromatography column (Superdex S200) as a single peak with retention volume compatible with a monomeric structure (Fig. 2B).

The purified RalXyn10A and RaldN34Xyn10A were active, with specific activity (measured with the soluble substrate MetGlcA-xylan) values of $90 \mathrm{U} / \mathrm{mg}$ and $50 \mathrm{U} / \mathrm{mg}$, respectively. Both enzymes exhibited similar dependence of activity and stability with temperature and $\mathrm{pH}$ (Fig. 3). Indeed, the optimal temperature for catalysis was $40^{\circ} \mathrm{C}$, and the analysis of stability by incubation at different temperatures showed a similar denaturation pattern for both proteins over $40^{\circ} \mathrm{C}$ (Fig. 3A). Regarding $\mathrm{pH}$, the higher activity was measured at pH 6.0 (Fig. 3B), and both enzymes were stable to the incubation in the range $\mathrm{pH} 4-8$ (Fig. S3).

We evaluated possible functions of the N34 domain for catalysis or binding to polysaccharides (CBM). Fig. 4 details saturation curves for the soluble substrate respect to the enzymes under study. As shown, the kinetic behavior for the use of MetGlcA-xylan was similar for RalXyn10A and Ral $\Delta$ N34Xyn10A, the former exhibiting enhanced hydrolytic capacity ( $\sim 2$-fold higher $V_{\text {max }}$ ). On the other hand, we assessed the ability of RalXyn10A and Ral $\Delta$ N34Xyn10A to bind to different insoluble polysaccharides with $\beta$-glycosidic linkages. As controls, we used a $\beta$-glucosidase from $T$. brockii ( $\mathrm{Tb} \mathrm{CglT}$ ) composed only of a GH10 catalytic core and the chimeric protein produced by fusing the N34 domain from RalXyn10A to TbrCglT (N34-TbrCglT). The wild type $R$. albus enzyme exhibited a relatively high capacity for binding to pine sawdust, filter paper, cellulose, and chitin (Fig. 5). The binding ability was lower for arabinoxylan, which could be due to arabinose ramifications present in arabinoxylan $[46,47]$. The truncated mutant protein, lacking the N34 domain, showed a low capacity to bind to the insoluble polysaccharide by $\sim 30 \%$ (for arabinoxylan, this reduction was $\sim 90 \%$ ). Concerning TbrCglT, it remained unbounded in the supernatant fraction or poorly
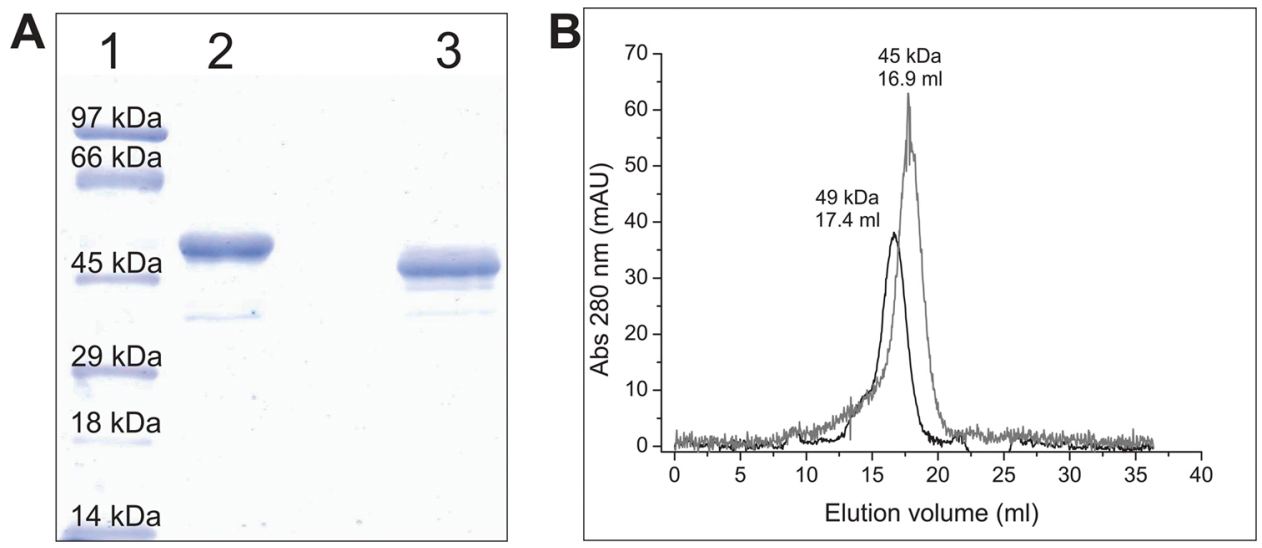

Fig. 2. Analysis of RalXyn10A and RalsN34Xyn10 purification by SDS-Page (A) and size exclusion chromatography profiles (B). Lane 1, molecular mass markers. Lane 2, purified RalXyn10A. Lane 3, purified RalsN34Xyn10. Both proteins eluted as a single peak with retention volume compatible with a monomeric structure. 

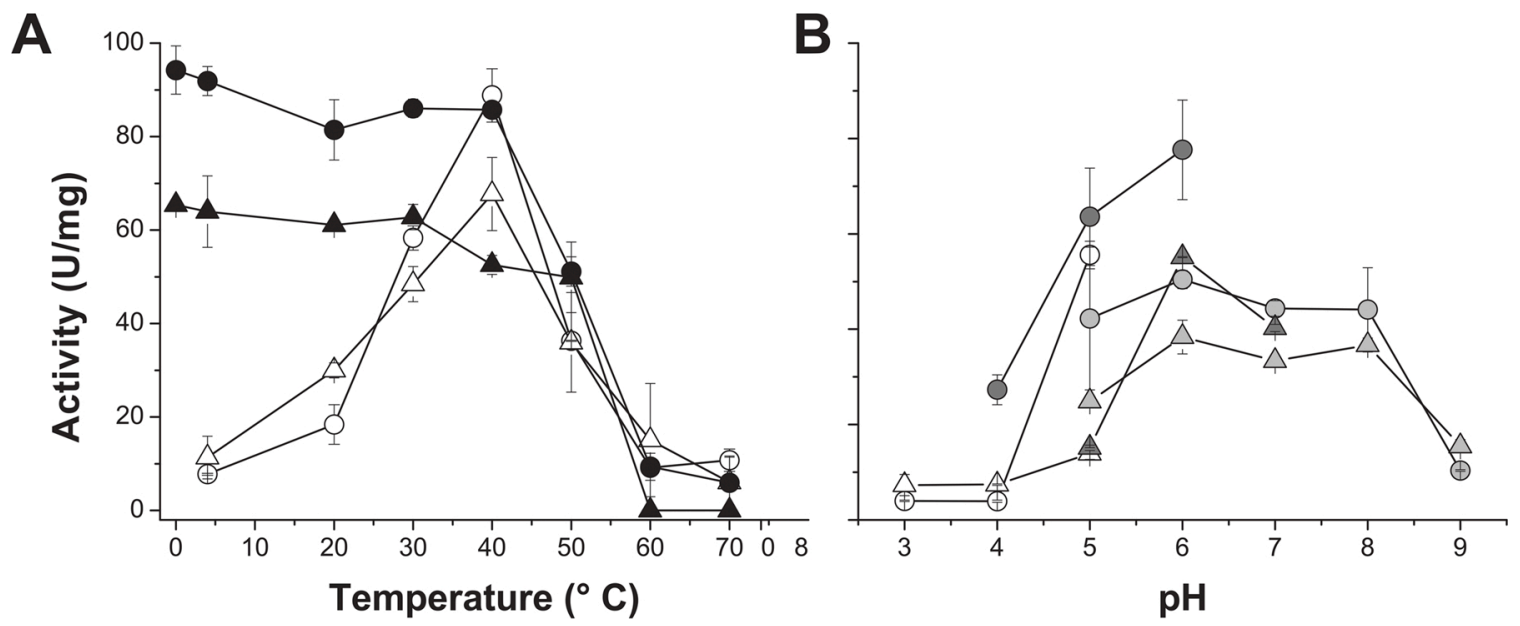

Fig. 3. Temperature (A) and pH profiles (B) of RalXyn10A ( $(\circ)$ and Ral $\mathbf{N} 34 \mathrm{Xyn} 10 \mathrm{~A}(\Delta)$. The optimum temperature profile is represented with empty symbols and denaturalization patterns with full symbols. Each color represents different buffer species: white for citrate buffer, gray for acetate buffer, and light gray phosphate buffer.

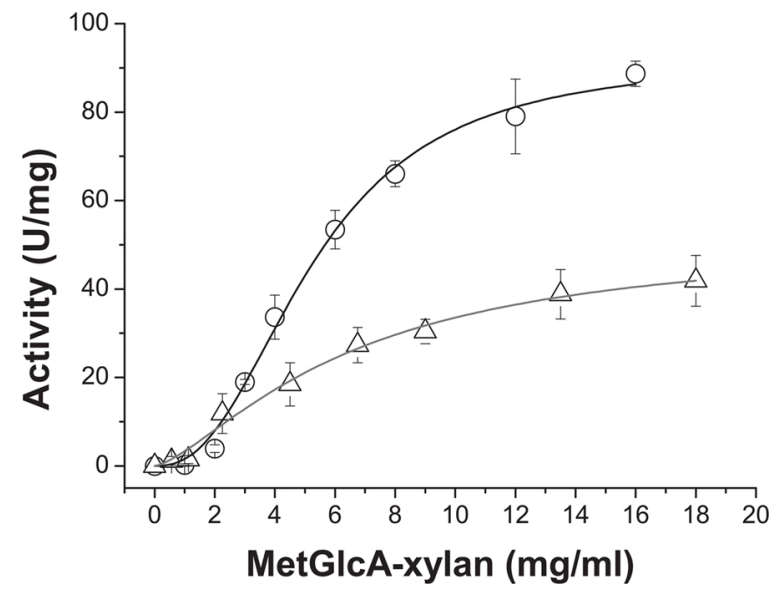

Fig. 4. Saturation curves for RalXyn10A (०) and RalsN34Xyn10A ( $\Delta$ ) with 4-methyl-D-glucurono-xylan as substrate. Parameters were calculated from average data from three independent experiments.

bound to the polymers. The N34-TbrCglT showed increased (by $10 \%$ or more) capacity for binding to pine sawdust and filter paper (Fig. 5).

\subsection{Redox modification of RalXyn10A}

We found that the activity of recombinant RalXyn10A was sensitive to the incubation with the reducing agents 2-mercaptoethanol (2ME) and dithiothreitol (DTT). Fig. 6A illustrates that the enzyme decreased its activity after $20 \mathrm{~min}$ treatment in a form that directly relates to the reductant concentration. As shown, the inhibition reaches a value of $\sim 80 \%$ at levels of $2 \mathrm{ME}$ or DTT of $1-5 \mathrm{mM}$. The inhibitory effect could be reversed by treatment with the oxidizing compounds $\mathrm{H}_{2} \mathrm{O}_{2}$ and diamide (Fig. 6B). Such a reversion also exhibited a direct dependency on the oxidant concentration. The inactivated enzyme could recover near $100 \%$ of the activity at $15 \mathrm{mM}$ of such agents. The reduction with $3 \mathrm{mM}$ DTT also affected the enzyme's capacity to bind to pine sawdust, with a decrease of $50 \%$ respect to the oxidized protein (data not shown). Interestingly, the truncated Ral $\Delta \mathrm{N} 34 \mathrm{Xyn} 10 \mathrm{~A}$ mutant was insensitive to redox treatment, and neither change was observed in its activity (Fig. 6A), nor in its ability to interact with the insoluble pine wood.

The above-detailed results lead us to identify cysteine residues (which preferentially undergo redox modification) in the sequence of RalXyn10A. One o such amino acid (Cys-5) is present in the N34 domain.

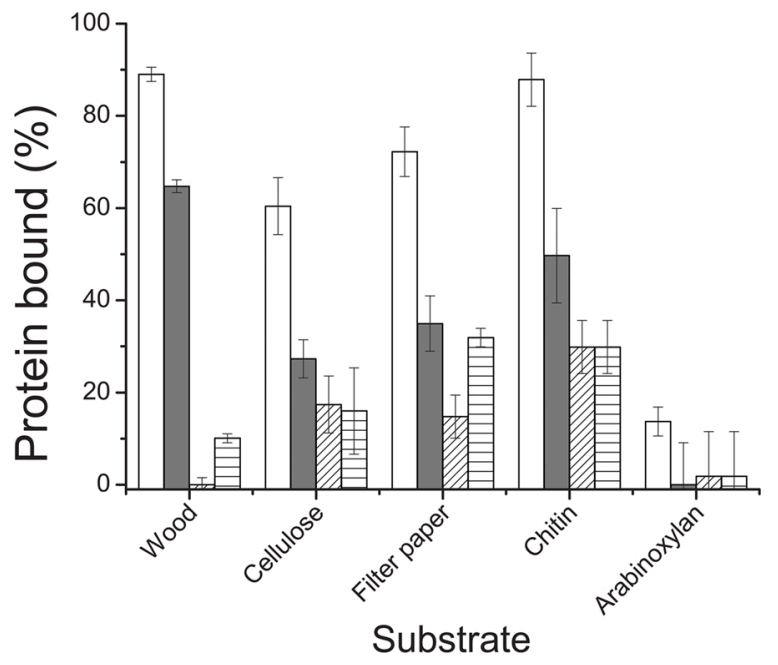

Fig. 5. Enzyme binding to insoluble substrates. Enzyme variants were incubated with insoluble polysaccharides ( $1 \% \mathrm{p} / \mathrm{v})$, including wood from pine tree, cellulose, filter paper, chitin, and arabinoxylan. After centrifugation, protein remains in the supernatant was quantify by Bradford procedure. RalXyn10A (white), RalsN34Xyn10A (gray), TbrCglT (diagonal stripe), N34TbrCglT (horizontal stripe).

Since the truncated enzyme lacked sensitivity to redox agents, Cys-5 would be a clear candidate to participate in the process. The protein has four other cysteines in the GH10 domain (at positions 78, 111, 200, and 270) that potentially could be involved in the redox modification, preferentially, if in the active site domain. Considering that the oxidation of two cysteinyl moieties to form a disulfide requires a relatively short distance between them, it was useful to have a 3D model of the GH10 domain. Several homologous 3D structures to RalXyn10A were found by HHBlits [37], but none of them include the N34 domain unique of RalXyn10A. Thus, we modeled the GH10 domain counting from residue 35-372, using the crystal structure model of endo-beta-1, 4-D-xylanase10B from Clostridium thermocellum (PDB ID: 2W5F) that showed the best identity (36\%) with RalXyn10A.

Our 3D model (Fig. 7) shows that residues present in the substratebinding cleft subsite -1 (Gln-263, Lys-83, Trp-336, Asn-187, His-128, His-265, and Trp-344) and subsite 2 (Glu-79, Asn-80) (all conserved between Xyn10As) are accurately positioned [48,49] (see Fig. S4). In such a 3D arrangement, one conserved (Cys-78) and other 

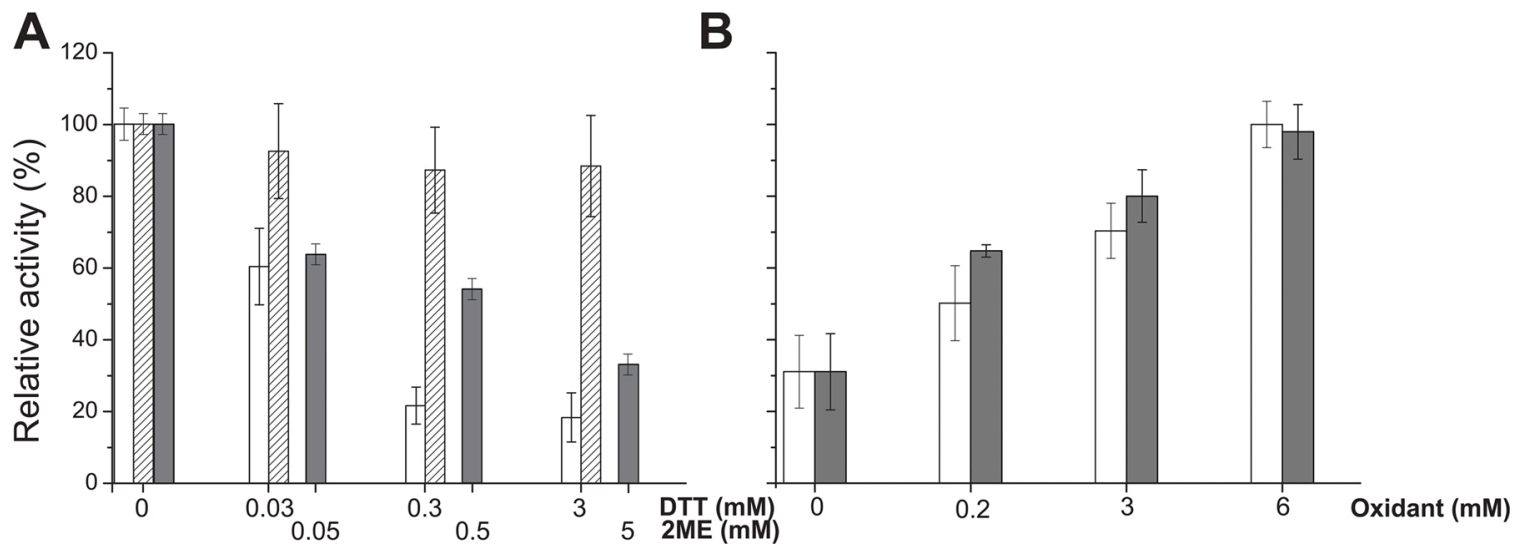

Fig. 6. Relative activity of RalXyn10A (white and gray stripes) and Ral $\Delta \mathrm{N} 34 \mathrm{Xyn} 10 \mathrm{~A}$ (diagonal stripes) after reduction treatments (A) and RalXyn10A subsequently oxidized with different concentrations of $\mathrm{H}_{2} \mathrm{O}_{2}$ (gray) and diamide (white) (B). The enzyme was incubated for 20 min with varying concentrations of redox agents (DTT and 2ME), and relative activity was measured in comparison with no treatment control. Hundred percent of activity ( 90 U. mg ${ }^{-1}$ ) corresponds to the control of the untreated enzyme.

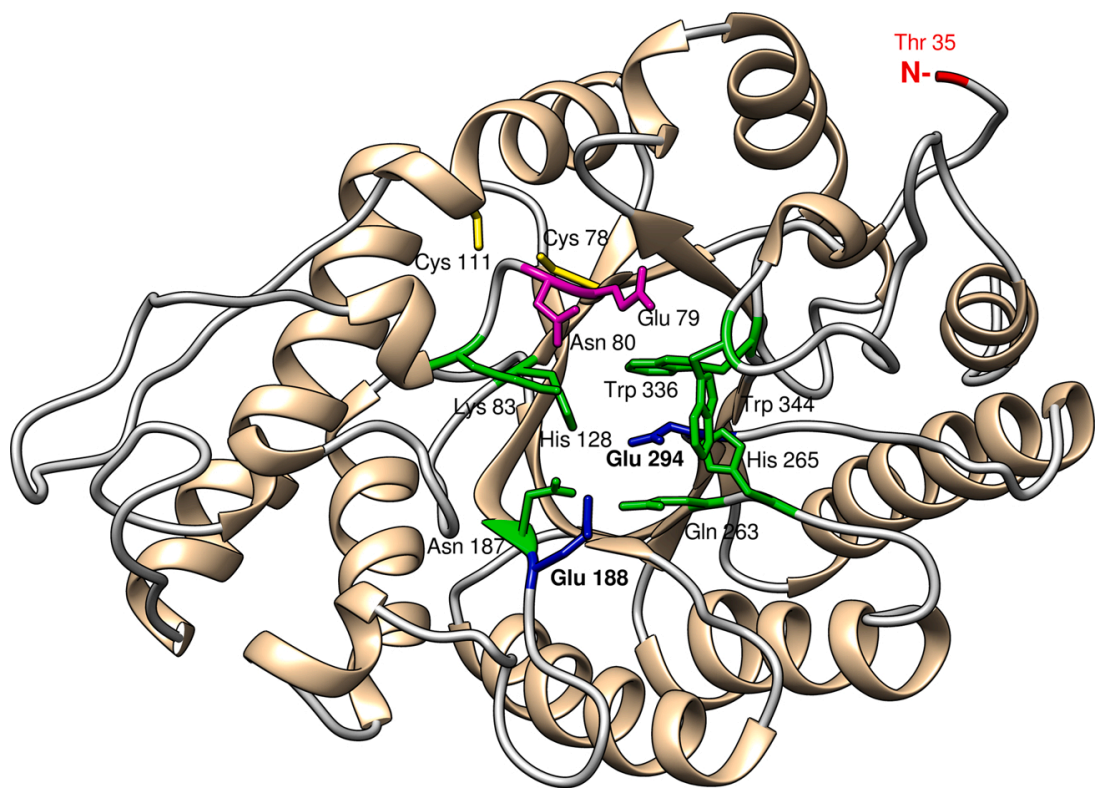

Fig. 7. Three-dimensional model of the GH10 catalytic domain of RalXyn10A. The building of the structure model of RalXyn10A was based in a template derived from a known Xray structure of endo- $\beta$-1,4-D-xylanase10B from C. thermocellum (PDB ID: 2W5F, Identity $36 \%$ ) [36]. Amino acids involved in substrate binding sites were displayed in green for subsite -1 , purple for subsite -2 , and catalytic glutamic acids (188 and 294) in blue (For interpretation of the references to colour in this figure legend, the reader is referred to the web version of this article.).

non-conserved (Cys-111) cysteines are relatively close ( $3 \AA$ A) each other and locate in the proximity of the substrate-binding subsites of RalXyn10A. The two other residues (Cys-200 and Cys-270) are distant between them, respect to other cysteines, and residues of relevance for the enzyme functionality. In this scenario, Cys-78 and Cys-111 would play an important function in maintaining the cleft structure for substrate binding. They could also be involved in the redox modification of the $R$. albus xylanase.

To insight the redox modification of RalXyn10A at a molecular level, we constructed and characterized three site-directed mutants of the protein (C5S, C78S, and C111S). C5S and C78S exhibited insensitivity to the incubation with DTT respect to changes in activity (Fig. 8A) or the capacity to bind to pinewood (Fig. 8B), thus resembling the behavior of Ral $\Delta$ N34Xyn10A. Table 1 details the kinetic parameters for the hydrolysis of MetGlcA-xylan of the wild type, N34-truncated, and cysteinyl mutant variants of the enzyme in their respective oxidized and reduced states. As shown, all the protein forms exhibited similar relative affinity toward the soluble substrate, although with a variable cooperativity degree (the higher for the reduced wild type and the C111S mutant) in the saturation curve. Contrarily, the different forms of the enzyme showed distinct $k_{\text {cat }}$ values.
Results in Table 1 indicate that the N34 domain and specifically the residue Cys- 5 are critical for RalXyn10A to reach a redox-dependent maximal catalytic capacity. Indeed, the entire protein at the oxidized state exhibited a $\sim 2$-fold enhancement of $k_{\text {cat }}$ with concerning (i) its reduced form, (ii) the Ral $\Delta \mathrm{N} 34 \mathrm{Xyn} 10 \mathrm{~A}$, and (iii) the C5S mutant enzyme. The C111S protein exhibited a behavior quite similar to the wild type enzyme, supporting a role of Cys-78 in the redox process (besides the involvement of Cys- 5 suggested before). More intriguing are the C78S enzyme characteristics since it displayed a $k_{\text {cat }}$ even higher (by $20 \%$ up) than the wild type protein. Besides, the activity of C78S was insensitive to treatment with DTT, which suggests that this protein form is intrinsically more active or that the oxidation process in this mutant takes place in a different (irreversible) manner.

Given the modification of the activity of RalXyn110A exerted by oxidant and reducing agents, we performed a redox titration associated with the enzyme catalytic capacity. The activity of the wild type and mutant forms of the xylanase was determined at different redox potentials $\left(E_{h}\right)$ reached by specific ratios of $2 \mathrm{ME}$ and its oxidized form (hydroxyethyl disulfide, HEDS) present into the assay media. The activity of RalXyn110A and the C111S mutant form increased from $40 \mathrm{U} /$ $\mathrm{mg}$ as the $\mathrm{E}_{\mathrm{h}}$ became less negative (more oxidizing), to reach its maximal 

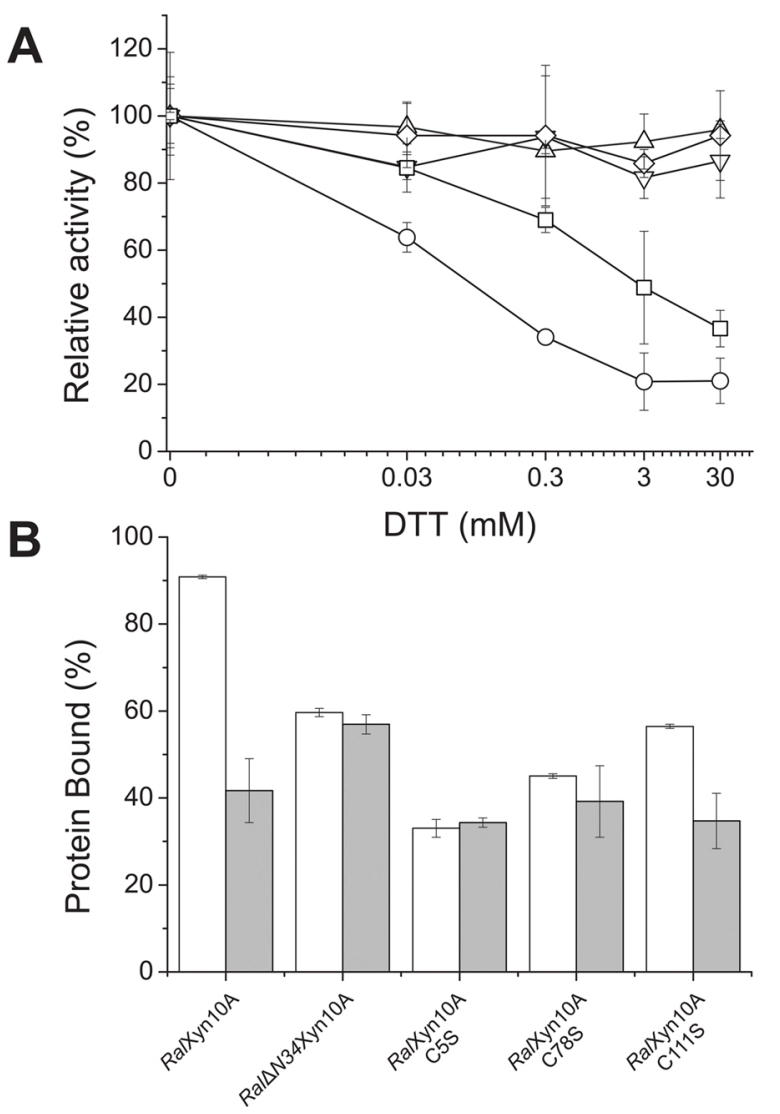

Fig. 8. Effect of reduction treatment by DTT on enzyme variants activity (A) and binding capacity (B). Enzyme variants $(3 \mu \mathrm{M})$ were incubated for 20 min with different concentrations of DTT $(0-30 \mathrm{mM})$, and enzyme activity was measured with MetGlcA-xylan. RalXyn10A (o), Ral $\Delta$ N34Xyn10A ( $\Delta$ ), RalXyn10A C5S ( $\nabla)$, RalXyn10A C78S ( $\diamond)$, RalXyn10A C111S ( $\square)$. For binding assays, oxidized (white) and reduced enzymes (gray) were incubated for $1 \mathrm{~h}$ with pine sawdust $(1 \% \mathrm{p} / \mathrm{v})$. Bound protein was determined as described in materials and methods.

Table 1

Kinetics parameters for enzyme variants with 4-O-methyl-D-glucuronoxylan as substrate.

\begin{tabular}{|c|c|c|c|c|}
\hline Enzyme Variant & DTT (mM) & $S_{0.5}(\mathrm{mg} / \mathrm{mL})$ & $n_{\mathrm{H}}$ & $k_{\text {cat }}\left(\mathrm{s}^{-1}\right)$ \\
\hline \multirow{2}{*}{ RalXyn10A } & 0 & $5.3 \pm 0.3$ & $2.4 \pm 0.2$ & $75 \pm 3$ \\
\hline & 3 & $5.4 \pm 0.2$ & $3.6 \pm 0.4$ & $47 \pm 2$ \\
\hline \multirow{2}{*}{ Ral $\Delta$ N34Xyn10A } & 0 & $6.0 \pm 0.5$ & $1.4 \pm 0.2$ & $39 \pm 4$ \\
\hline & 3 & $6.0 \pm 0.5$ & $1.4 \pm 0.2$ & $39 \pm 5$ \\
\hline \multirow{2}{*}{ RalXyn10A C5S } & 0 & $6.0 \pm 0.5$ & $1.4 \pm 0.2$ & $48 \pm 5$ \\
\hline & 3 & $6.4 \pm 0.4$ & $2.3 \pm 0.2$ & $52 \pm 2$ \\
\hline \multirow{2}{*}{ RalXyn10A C78S } & 0 & $4.7 \pm 0.5$ & $2.2 \pm 0.3$ & $83 \pm 6$ \\
\hline & 3 & $4.2 \pm 0.2$ & $2.6 \pm 0.3$ & $72 \pm 3$ \\
\hline \multirow{2}{*}{ RalXyn10A C111S } & 0 & $4.3 \pm 0.3$ & $3.1 \pm 0.5$ & $71 \pm 3$ \\
\hline & 3 & $4.5 \pm 0.2$ & $3.0 \pm 0.3$ & $53 \pm 2$ \\
\hline
\end{tabular}

"DTT: Enzyme $(3 \mu \mathrm{M})$ was incubated for $20 \mathrm{~min}$ at $30^{\circ} \mathrm{C}$ with DDT $3 \mathrm{mM}$.

value at $-150 \mathrm{mV}$ (Fig. 9). For the wild type and the mutant proteins, the $\mathrm{E}_{\mathrm{m}}$ (potential at which the activity reached $50 \%$ of the total increase) was determined in $-290 \mathrm{mV}$ and $-230 \mathrm{mV}$, respectively. In agreement with the other results reported herein, the activity of Ral $\Delta \mathrm{N} 34 \mathrm{Xyn} 10 \mathrm{~A}$, as well as of the mutants C5S, and C78S, remained unchanged within the range of redox potential analyzed.

\subsection{Expanded approach on the structure-function of the N34 domain}

As analyzed above, the N34 motif of RalXyn10A contains a cysteine

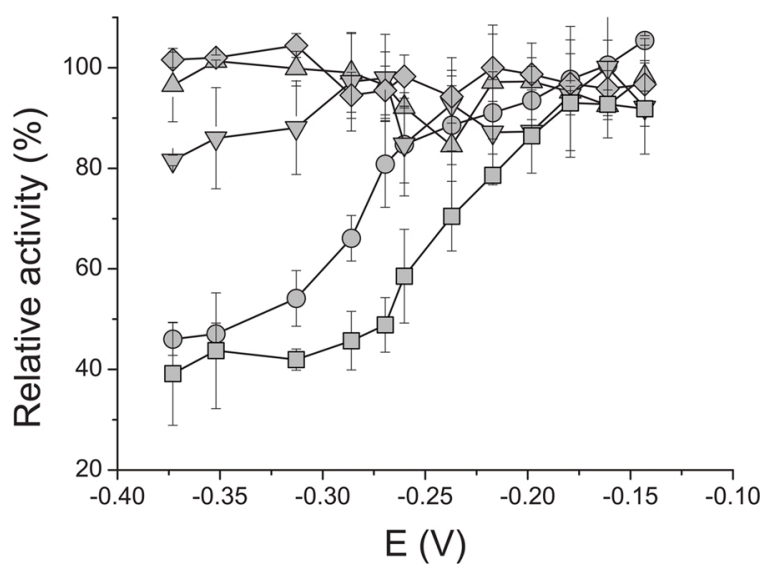

Fig. 9. Determination of midpoint reduction potential. Redox titration of the different enzyme variants $(5 \mu \mathrm{M})$ incubated at $30^{\circ} \mathrm{C}$ and $\mathrm{pH} 8.0$ with various $2 \mathrm{ME} / \mathrm{HEDS}$ ratios for $1 \mathrm{~h}$. The titration curve was fitted as the reduced fraction versus $E_{\mathrm{h}}$ using a logistic model.

residue that would critically participate in forming a disulfide bridge with a similar residue located in the protein's GH10 domain. The redox process generates a more active enzyme, having a moderate enhanced affinity for the binding to insoluble substrates. This latter feature agrees, in part, with a degree of similarity ( $23 \%$ ) found by sequence alignment with CBM37 (see Fig. S2). This domain is characteristic of glycosyl hydrolases of $R$. albus (i.e., Cel48A, Cel9B, Cel5G, and Xyn10B), conferring these enzymes capacity to bind polysaccharides and interact with cell membranes [50]. Nevertheless, even when it is the higher regarding CBMs, the similitude with CBM37 is relatively low to typify N34 as a domain of such a nature (as least primarily). Besides, we performed multiple sequence alignments with dockerins and pili-like proteins, which are extracellular molecular components involved in cellulosome assembling or in the interaction with fibril polysaccharides, that were previously reported in $R$. albus [51,52]. Results of these alignments gave even lower sequence similarities $(\sim 5-10 \%$, see Fig. S5), thus suggesting the lack of dockerin and pili-like protein function for the N34 motif.

We inverted the strategy to find possible similitude with proteins of known function, now using the N34 amino acid sequence as the query to BLAST against the universe of polypeptide domains in the database. As shown in Fig. 10A, by this procedure, we identified a significant similarity ( $\sim 50 \%)$ with SBP (for Substrate Binding Protein) of $\mathrm{ABC}$ (abbreviation of ATP-Binding Cassette) transporters present in membranes of many bacteria [53-55]. The similitude percentage is in agreement with the structural similarity between SBP proteins and the model of the N34 domain obtained based on of threading with ten templates (Fig. 10B). This result strongly supports the role of N34 in connecting RalXyn10A with the bacterium membrane, probably coupling the saccharides interacting with the enzyme with the transport of monosaccharide products to be incorporated into the cell. We further compared the N34 sequence with the proteins database of $R$. albus (Fig. S6), revealing its presence in a group of seventeen proteins that include: (i) nine of the families of transglutaminase (five), ColH kinase (two), and glycosyl hydrolase (two); and (ii) eight cataloged as putative proteins without assigned function.

\section{Discussion}

The production of biofuels from lignocellulosic materials requires the enzymatic hydrolysis of cellulosic substrates (cellulose and hemicellulose) to fermentable sugars. The enzymes hydrolyzing cellulose and hemicellulose usually arrange in a multi-enzymatic complex known as cellulosome, particularly in anaerobic microorganisms [57,58]. Cellulosomes set up the scaffolding of proteins anchored to the cell membrane 


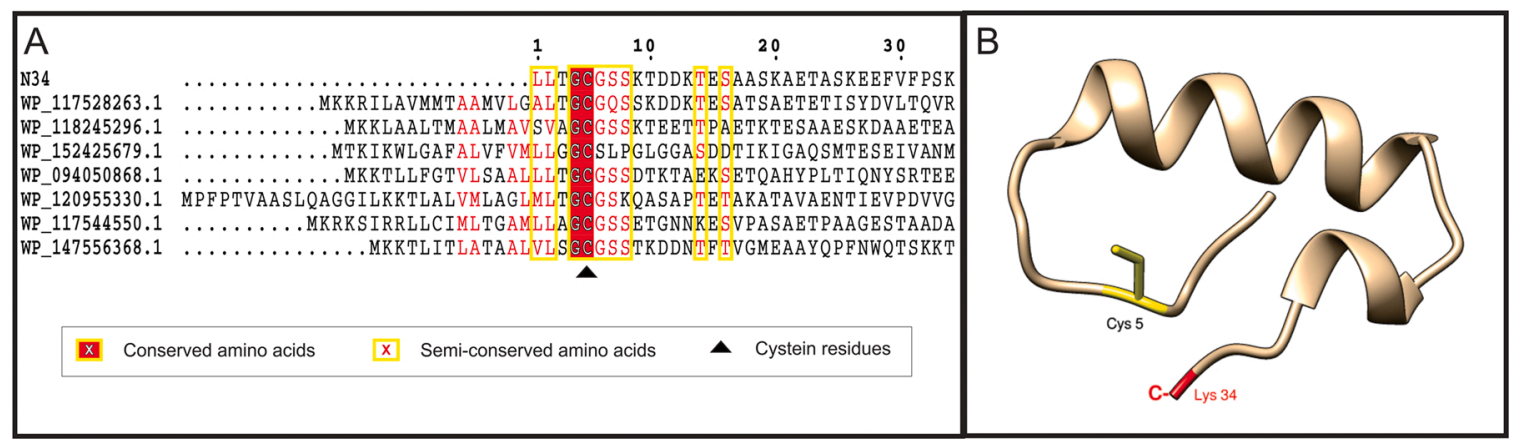

Fig. 10. Proteins containing a N34 similar motif (A) and 3D model by threading of the N34 motif (B). RalXyn10A N-terminal amino acids (N34) were used a query in a BLAST search to identify sequences that contain a similar motif. WP_117528263.1, ABC transporter substrate-binding protein from Coprococcus catus (Sim: 50 \%, Id: 41 \%;151 aa); WP_118245296.1, transporter substrate-binding domain-containing protein from Clostridium sp. AM58-1XD (Sim: 41 \%, Id: 26 \%; 568 aa); WP_152425679.1 osmoprotectant ABC transporter substrate-binding protein from Bacillus subtilis (Sim: 29 \%, Id: 15 \%;151 aa); WP_094050868.1, ABC transporter substrate-binding protein from unclassified Cohnella (Sim: $35 \%$, Id: $29 \%$;36 aa); WP_120955330.1, PASTA domain-containing protein from Arthrobacter_oryzae (Sim: 41 \%, Id: 32 \%; 209 aa); WP_117544550.1, extracellular solute-binding protein from Eisenbergiella massiliensis (Sim: 47 \%, Id: 41 \%; 555 aa); WP_147556368.1, transporter substrate-binding domain-containing protein from Catenibacterium mitsuokai (Sim: $41 \%$, Id: $29 \% ; 270$ aa). B) The building of the structure model of N34 was made by I-TASSER server. Amino acid cysteine 5 that is involved in redox modulation is highlighted in yellow and carboxyl terminal lysine 34 that connects the N34 to the catalytic domain in red (For interpretation of the references to colour in this figure legend, the reader is referred to the web version of this article.).

that coordinate the recruitment of cellulolytic enzymes through the interaction of dockerin-cohesin domains. The consequence is that the hydrolytic enzymes and their catalysis products remain close to the cell surface [56,57]. Regarding $R$. albus, the molecular mechanisms to stick proteins to lignocellulose were scarcely determined, with the proposal of many differences to what was found in Clostridium spp. and even in Ruminococcus flavefaciens [59]. In the former bacterium, it has been identified the occurrence of the extracellular glycocalyx [60], pili-like structures composed by proteins $\mathrm{CbpC}[52,61]$, and cellulosome-like complexes [52]. Besides, it was reported that the CBM37 domain not only plays the canonical role of gathering glycosyl hydrolases to polysaccharides but also is involved in the stick of the enzymes to the cell membrane [50].

The exhaustive biochemical analysis of the genome from $R$. albus 8 respect to enzymes degrading the hemicellulose component of the plant cell wall shows five putative endoxylanases, two belonging to the GH10, and three to the GH11 family [22]. These enzymes operate synergistically with a $\beta$-xylosidase, an $\alpha$-L-arabinofuranosidase, and an $\alpha$-glucuronidase that would constitute accessory components to hydrolyze further the products of the formers [20,22]. All five endoxylanases have been studied [22], with the RalXyn10A in this group characterized as the simplest in structure, being composed of only a GH10 catalytic domain [22]. Indeed, the enzyme is markedly different to Xyn10B, which central GH10 module (catalytic) is flanked by a CBM4_9, and a CBM22 plus a CBM37 at the $\mathrm{N}$ - and the $\mathrm{C}$-terminus, respectively. We performed a more detailed analysis to revisit that the 377 amino acids RalXyn10A protein comprises not only a GH10 catalytic module but also an N-terminal domain of 34-amino acids (N34) with no assigned putative role. This latter raised the question about a possible functionality for such an N34 sequence, after which we produced recombinant RalXyn10A and the truncated Ral $\Delta$ N34Xyn10A mutant enzyme and characterized the properties of the purified proteins.

Our results support the N34 module's functionality in RalXyn10A, with characteristics that improve the catalytic capacity. The enzyme's complete form exhibited a higher capability to bind insoluble polysaccharide substrates than the truncated mutant. Besides, the chimeric protein (N34-TbrCglT) revealed that the fused N34 motif improved the binding of the $\beta$-glucosidase the polymeric substrates. These behaviors agree with the action exerted by CBM from multimodular enzymes [14, 15]. Worthy, N34 seems to be an atypical CBM, considering its relatively low similarity with other modules already characterized [19]. This little sequence correspondence includes CBMs found for glycosidases from $R$. albus, with the best match of $15 \%$ identity and $23 \%$ similarity regarding the CBM37a from $R$. albus 8 .

A second function found for N34 in RalXyn10A is its involvement in a redox process where the Cys- 5 in the motif would form a disulfide bridge with a homologous residue located in the GH10 domain of the protein. In the oxidized form, the enzyme is up to 2 -fold more active (also having a higher capacity to bind insoluble polysaccharides). Changes in RalXyn10A activity resulted from treatments with reductants (DTT and 2ME) that inactivated, or oxidants $\left(\mathrm{H}_{2} \mathrm{O}_{2}\right.$ and diamide) that reversed the effect, recovering the activity. The characteristics of these redox agents' action suggest the oxidative formation of a disulfide bridge that is shifted to the originating cysteine residues upon reduction [62-64]. Supporting the involvement of Cys-5, the Ral $\Delta$ N34Xyn10A exhibited about half the activity of the entire oxidized enzyme and was insensitive to the redox treatments. Performing the redox treatment of the enzyme at variable ratios of $2 \mathrm{ME} / \mathrm{HEDS}$, we calculated an $\mathrm{E}_{\mathrm{h}}$ of $-290 \mathrm{mV}$ for the transition between low and high active forms RalXyn10A.Together with the fact that the enzyme is extracellular to $R$. albus, these redox conditions are compatible with the in vivo conditions where the enzyme is operative. Indeed, R. albus 8 is one of the organisms of the rumen microbiota in Bos taurus, including anaerobic/microaerophilic bacteria, fungi, and protozoan that help to degrade fiber and cellulosic/lignocellulosic components. The $\mathrm{E}_{\mathrm{h}}$ of the rumen environment was determined in the range $-220 \mathrm{mV}$ to $-110 \mathrm{mV}$ [65-67], after which RalXyn10A would reach its maximal catalytic capacity upon release from the cell bacterium.

Based on a 3D model of the GH10 catalytic module, we identified Cys-78 and Cys-111, as positioned in the enzyme active (and substrate binding) site. The mutant proteins $\mathrm{C} 5 \mathrm{~S}$ and $\mathrm{C78S}$ exhibited insensitive to redox treatment regarding their catalytic capacities, whereas the C111S mutant behaved like wild-type RalXyn10A. These results suggest that Cys-78 would be close enough to form the disulfide bridge with Cys- 5 producing the oxidized enzyme. Such a process would induce a conformational change to a more accurate protein structure with enhanced the capacity to bind substrate and perform the catalytic hydrolysis [62-64]. Besides, and interestingly, the $V_{\max }$ of C78S was $\sim 20$ $\%$ higher than that of the wild type enzyme. The absence of the Cys-78 would induce the oxidation of Cys- 5 to form a sulfenic acid state (which is not susceptible to reduction). This oxidized form could generate a sulfenamide derivative after reacting with an amine or amide moiety in the active site environment where localize the absent Cys-78, as it has been reported to occur in other proteins $[63,64]$. The sulfonamide produced in the $\mathrm{C} 78 \mathrm{~S}$ mutant protein would arrange a conformational change in the enzyme similar to that reached by RalXyn10A. The 
characteristics of higher activity and insensitivity to changes in the redox environment make the C78S mutant enzyme a relevant technological tool for biofuel and biorefinery industries.

Beyond the relevant functions at the redox-linked enhancement of the substrate binding capacity and catalysis exerted by RalXyn10A, the N34 would play a role in the association of the enzyme with components of the R. albus membrane. The finding supporting the latter is that the domain has a high degree of similarity with SBP polypeptides of ABC transporters already identified in membranes of many bacteria [53-55]. These systems work by arranging a scaffold of proteins and substrates in association with the membrane transporters to improve the cell intake of the enzymatic processes. A cluster of an ABC transporter component, including enzymes that hydrolyze xylans, was identified in $R$. flavefaciens [68]. Besides, it was reported that the growth of $R$. albus on cellulose induces a more than 4-fold increase in the level of transcripts related to an $\mathrm{ABC}$ transporter operon [59]. All the data support a scenario where the N34 domain could associate RalXyn10A to a multi-protein structure connected with the cell membrane. The protein complex would facilitate the accurate hydrolysis of xylans coupled to the products' handling for an adequate intake to the bacterial cell. Once established of the N34 sequence's functionality, the motif was found in other seventeen proteins of $R$. albus 8 already identified as an enzyme or only as putative macromolecules withoutassigned role. Thus, the present work contributes to evidence of a sequence domain that is functional to complement the action of different enzymes and proteins in the ruminal bacterium.

\section{Conclusions}

Ruminococcus albus 8 endo $\beta-1,4$ xylanase 10A (RalXyn10A) presents an N-terminus amino acid motif beside the GH10 catalytic domain that is distinctively functional. This domain plays a critical role in redox modulation of the xylanolytic activity of RalXyn10A in the rumen environment. Besides, our results show that N34 is involved in enzyme binding to polysaccharides and has significant similarity with SBP proteins from $\mathrm{ABC}$ transporters of the cell membrane. Previous research already demonstrated more than one mechanism involved with the adhesion of $R$. albus to the substrate [52], where CBM37 mediates the glycanases localization at the surface of the cell membrane [50]. Similarly, N34 may play a role in linking enzyme degradation of polysaccharides with the uptake of the products by the bacterium.

\section{Authors agreement}

All the authors have read and approved the present version of the manuscript. The manuscript reports unpublished work that is not under active consideration for publication elsewhere, it has not been accepted for publication nor been published in full or in part.

\section{Funding}

AS is a doctoral fellow from CONICET. AAI and SAG are investigator carrer members from CONICET. This work was supported by grants from CONICET (PUE 2016-0040 to IAL), ANPCyT (PICT-2015-1149 \& PICT2016-1110 to SAG, and PICT-2017-1515 \& PICT-2018-00929 to AAI).

\section{CRediT authorship contribution statement}

Alem Storani: Conceptualization, Methodology, Software, Validation, Formal analysis, Investigation, Data curation, Writing - original draft, Writing - review \& editing. Sergio A. Guerrero: Conceptualization, Methodology, Validation, Resources, Writing - original draft, Writing - review \& editing, Visualization, Supervision, Project administration, Funding acquisition. Alberto A. Iglesias: Conceptualization, Methodology, Validation, Resources, Writing - original draft, Writing review \& editing, Visualization, Supervision, Project administration,
Funding acquisition.

\section{Appendix A. Supplementary data}

Supplementary material related to this article can be found, in the online version, at doi:https://doi.org/10.1016/j.enzmictec.2020.10 9673.

\section{References}

[1] J. Cooper, J. Kavanagh, A. Razmjou, V. Chen, G. Leslie, Treatment and resource recovery options for first and second generation bioethanol spentwash - a review, Chemosphere. 241 (2020) 124975, https://doi.org/10.1016/j. chemosphere.2019.124975.

[2] R.E.H. Sims, W. Mabee, J.N. Saddler, M. Taylor, An overview of second generation biofuel technologies, Bioresour. Technol. 101 (2010) 1570-1580, https://doi.org/ 10.1016/j.biortech.2009.11.046.

[3] B. Yang, C.E. Wyman, Effect of xylan and lignin removal by batch and flowthrough pretreatment on the enzymatic digestibility of corn stover cellulose, Biotechnol. Bioeng. 86 (2004) 88-98, https://doi.org/10.1002/bit.20043.

[4] K. Öhgren, R. Bura, J. Saddler, G. Zacchi, Effect of hemicellulose and lignin removal on enzymatic hydrolysis of steam pretreated corn stover, Bioresour. Technol. 98 (2007) 2503-2510, https://doi.org/10.1016/j.biortech.2006.09.003.

[5] R. Kumar, C.E. Wyman, Effect of xylanase supplementation of cellulase on digestion of corn stover solids prepared by leading pretreatment technologies, Bioresour. Technol. 100 (2009) 4203-4213, https://doi.org/10.1016/j. biortech.2008.11.057.

[6] J. Zhang, P. Tuomainen, M. Siika-aho, L. Viikari, Comparison of the synergistic action of two thermostable xylanases from GH families 10 and 11 with thermostable cellulases in lignocellulose hydrolysis, Bioresour. Technol. 102 (2011) 9090-9095, https://doi.org/10.1016/j.biortech.2011.06.085.

[7] A. Berlin, N. Gilkes, D. Kilburn, R. Bura, A. Markov, A. Skomarovsky, O. Okunev, A. Gusakov, V. Maximenko, D. Gregg, A. Sinitsyn, J. Saddler, Evaluation of novel fungal cellulase preparations for ability to hydrolyze softwood substrates evidence for the role of accessory enzymes, Enzyme Microb. Technol. 37 (2005) 175-184, https://doi.org/10.1016/j.enzmictec.2005.01.039.

[8] Alokika, B. Singh, Production, characteristics, and biotechnological applications of microbial xylanases, Appl. Microbiol. Biotechnol. 103 (2019) 8763-8784, https:// doi.org/10.1007/s00253-019-10108-6.

[9] X. Chen, L. Xiong, H. Li, L. Zhang, G. Yuan, X. Chen, C. Wang, X. Chen, The inhibitory effect of xylan on enzymatic hydrolysis of cellulose is dependent on cellulose ultrastructure, Cellulose (2020) 1-12, https://doi.org/10.1007/s10570020-03087-9.

[10] G.O. Aspinall, Structural chemistry of the hemicelluloses, Adv. Carbohydr. Chem. 14 (1959) 429-468, https://doi.org/10.1016/S0096-5332(08)60228-3.

[11] P. Tomme, R.A.J. Warren, N.R. Gilkes, Cellulose hydrolysis by Bacteria and Fungi, Adv. Microb. Physiol. 37 (1995) 1-81, https://doi.org/10.1016/S0065-2911(08) 60143-5.

[12] S.F. Badino, S.J. Christensen, J. Kari, M.S. Windahl, S. Hvidt, K. Borch, P. Westh, Exo-exo synergy between Cel6A and Cel7A from Hypocrea jecorina: role of carbohydrate binding module and the endo-lytic character of the enzymes, Biotechnol. Bioeng. 114 (2017) 1639-1647, https://doi.org/10.1002/bit.26276.

[13] F. Contreras, S. Pramanik, A.M. Rozhkova, I.N. Zorov, O. Korotkova, A.P. Sinitsyn, U. Schwaneberg, M.D. Davari, Engineering robust cellulases for tailored lignocellulosic degradation cocktails, Int. J. Mol. Sci. 21 (2020) 1589, https://doi. org/10.3390/ijms21051589.

[14] A.B. Boraston, D.N. Bolam, H.J. Gilbert, G.J. Davies, Carbohydrate-binding modules: fine-tuning polysaccharide recognition, Biochem. J. 382 (2004) 769-781, https://doi.org/10.1042/BJ20040892.

[15] O. Shoseyov, Z. Shani, I. Levy, Carbohydrate binding modules: biochemical properties and novel applications, Microbiol. Mol. Biol. Rev. 70 (2006), 283 LP 295, http://mmbr.asm.org/content/70/2/283.abstract.

[16] S. Zhang, K. Zhang, X. Chen, X. Chu, F. Sun, Z. Dong, Five mutations in N-terminus confer thermostability on mesophilic xylanase, Biochem. Biophys. Res. Commun. 395 (2010) 200-206, https://doi.org/10.1016/j.bbrc.2010.03.159.

[17] L. Liu, G. Zhang, Z. Zhang, S. Wang, H. Chen, Terminal amino acids disturb xylanase thermostability and activity, J. Biol. Chem. 286 (2011) 44710-44715, https://doi.org/10.1074/jbc.M111.269753.

[18] S. Zhang, Y. He, H. Yu, Z. Dong, Seven N-terminal residues of a thermophilic xylanase are sufficient to confer hyperthermostability on its mesophilic counterpart, PLoS One 9 (2014), e87632, https://doi.org/10.1371/journal. pone.0087632.

[19] V. Lombard, H. Golaconda Ramulu, E. Drula, P.M. Coutinho, B. Henrissat, The carbohydrate-active enzymes database (CAZy) in 2013, Nucleic Acids Res. 42 (2014), https://doi.org/10.1093/nar/gkt1178.

[20] L.C. Greve, J.M. Labavitch, R.E. Hungate, $\alpha$-L-Arabinofuranosidase from Ruminococcus albus 8: purification and possible role in hydrolysis of alfalfa cell wall, Appl. Environ. Microbiol. 47 (1984) 1135-1140, https://doi.org/10.1128/ aem.47.5.1135-1140.1984.

[21] M. Nakamura, T. Nagamine, A. Takenaka, R.I. Aminov, K. Ogata, K. Tajima, H. Matsui, Y. Benno, H. Itabashi, Molecular cloning, nucleotide sequence and characteristics of a xylanase gene (xynA) from Ruminococcus albus 7, Anim. Sci. J. 73 (2002) 347-352, https://doi.org/10.1046/j.1344-3941.2002.00048.x. 
[22] Y.H. Moon, M. Iakiviak, S. Bauer, R.I. Mackie, I.K.O. Cann, Biochemical analyses of multiple endoxylanases from the rumen bacterium Ruminococcus albus 8 and their synergistic activities with accessory hemicellulose-degrading enzymes, Appl. Environ. Microbiol. 77 (2011) 5157-5169, https://doi.org/10.1128/AEM.0035311.

[23] J.M. Leatherwood, Cellulase complex of Ruminococcus and a new mechanism for cellulose degradation, Adv. Chem. Ser. (1969) 53-59, https://doi.org/10.1021/ba1969-0095.ch005.

[24] Q. Xu, M. Morrison, K.E. Nelson, E.A. Bayer, N. Atamna, R. Lamed, A novel family of carbohydrate-binding modules identified with Ruminococcus albus proteins, FEBS Lett. 566 (2004) 11-16, https://doi.org/10.1016/j.febslet.2004.04.005.

[25] J. Sambrook, D.W. Russell, Molecular Cloning, A Laboratory Manual, the Thir Edition, Cold Spring Horbor laboratory Press, 2001.

[26] R. Breves, K. Bronnenmeier, N. Wild, F. Lottspeich, W.L. Staudenbauer, J. Hofemeister, Genes encoding two different $\beta$-glucosidases of Thermoanaerobacter brockii are clustered in a common operon, Appl. Environ. Microbiol. 63 (1997) 3902-3910, https://doi.org/10.1128/aem.63.10.39023910.1997.

[27] M.M. Bradford, A rapid and sensitive method for the quantitation of microgram quantities of protein utilizing the principle of protein-dye binding, Anal. Biochem 72 (1976) 248-254, https://doi.org/10.1016/0003-2697(76)90527-3.

[28] R. Kumar, C.E. Wyman, Effect of xylanase supplementation of cellulase on digestion of corn stover solids prepared by leading pretreatment technologies, Bioresour. Technol. 100 (2009) 4203-4213, https://doi.org/10.1016/j. biortech.2008.11.057.

[29] F. Green, C.A. Clausen, T.L. Highley, Adaptation of the Nelson-Somogyi reducingsugar assay to a microassay using microtiter plates, Anal. Biochem. 182 (1989) 197-199, https://doi.org/10.1016/0003-2697(89)90578-2.

[30] M.J. Bailey, P. Biely, K. Poutanen, Interlaboratory testing of methods for assay of xylanase activity, J. Biotechnol. 23 (1992) 257-270, https://doi.org/10.1016/ 0168-1656(92)90074-J.

[31] F.Q. Schafer, G.R. Buettner, Redox environment of the cell as viewed through the redox state of the glutathione disulfide/glutathione couple, Free Radic. Biol. Med. 30 (2001) 1191-1212, https://doi.org/10.1016/S0891-5849(01)00480-4.

[32] W.J. Lees, G.M. Whitesides, Equilibrium constants for thiol-disulfide interchange reactions: a coherent, corrected set, J. Org. Chem. 58 (1993) 642-647, https://doi. org/10.1021/jo00055a016.

[33] F. Sievers, D.G. Higgins, Clustal Omega for making accurate alignments of many protein sequences, Protein Sci. 27 (2018) 135-145, https://doi.org/10.1002/ pro.3290.

[34] X. Robert, P. Gouet, Deciphering key features in protein structures with the new ENDscript server, Nucleic Acids Res. 42 (2014), https://doi.org/10.1093/nar/ gku316.

[35] M. Biasini, S. Bienert, A. Waterhouse, K. Arnold, G. Studer, T. Schmidt, F. Kiefer, T. G. Cassarino, M. Bertoni, L. Bordoli, T. Schwede, SWISS-MODEL: Modelling protein tertiary and quaternary structure using evolutionary information, Nucleic Acids Res. 42 (2014), https://doi.org/10.1093/nar/gku340.

[36] S. Najmudin, B.A. Pinheiro, J.A.M. Prates, H.J. Gilbert, M.J. Romão, C.M.G. A. Fontes, Putting an N-terminal end to the Clostridium thermocellum xylanase Xyn10B story: crystal structure of the CBM22-1-GH10 modules complexed with xylohexaose, J. Struct. Biol. 172 (2010) 353-362, https://doi.org/10.1016/j. jsb.2010.07.009.

[37] M. Remmert, A. Biegert, A. Hauser, J. Söding, HHblits: Lightning-fast iterative protein sequence searching by HMM-HMM alignment, Nat. Methods 9 (2012) 173-175, https://doi.org/10.1038/nmeth.1818.

[38] B. Webb, A. Sali, Comparative protein structure modeling using MODELLER. Curr. Protoc. Bioinforma, John Wiley \& Sons, Inc., 2014, pp. 1-32, https://doi.org/ 10.1002/0471250953.bi0506s47.

[39] B. Webb, A. Sali, Protein structure modeling with MODELLER, Methods Mol. Biol. 1137 (2014) 1-15, https://doi.org/10.1007/978-1-4939-0366-5_1.

[40] D. Eisenberg, R. Lüthy, J.U. Bowie, VERIFY3D: Assessment of protein models with three-dimensional profiles, Methods Enzymol. 277 (1997) 396-404, https://doi. org/10.1016/S0076-6879(97)77022-8.

[41] M. Shen, A. Sali, Statistical potential for assessment and prediction of protein structures, Protein Sci. 15 (2006) 2507-2524, https://doi.org/10.1110/ ps.062416606.

[42] P. Benkert, M. Künzli, T. Schwede, QMEAN server for protein model quality estimation, Nucleic Acids Res. 37 (2009), https://doi.org/10.1093/nar/gkp322.

[43] A. Drozdetskiy, C. Cole, J. Procter, G.J. Barton, JPred4: A protein secondary structure prediction server, Nucleic Acids Res. 43 (2015) W389-W394, https://doi org/10.1093/nar/gkv332.

[44] Y. Zhang, I-TASSER Server for Protein Structure and Function Prediction, BMC Bioinformatics, 2008 (accessed May 20, 2020), https://zhanglab.ccmb.med.umich. edu/I-TASSER/.

[45] C. Zhang, P.L. Freddolino, Y. Zhang, COFACTOR: Improved protein function prediction by combining structure, sequence and protein-protein interaction information, Nucleic Acids Res. 45 (2017) W291-W299, https://doi.org/10.1093/ nar/gkx366.

[46] D.S. Lee, K.H. Lee, E.J. Cho, H.M. Kim, C.S. Kim, H.J. Bae, Characterization and pH-dependent substrate specificity of alkalophilic xylanase from Bacillus alcalophilus, J. Ind. Microbiol. Biotechnol. 39 (2012) 1465-1475, https://doi.org/ 10.1007/s10295-012-1159-0.

[47] A. Teleman, M. Tenkanen, A. Jacobs, O. Dahlman, Characterization of O-acetyl-(4O-methylglucurono)xylan isolated from birch and beech, Carbohydr. Res. 337 (2002) 373-377, https://doi.org/10.1016/S0008-6215(01)00327-5.

[48] G.J. Davies, K.S. Wilson, B. Henrissat, Nomenclature for sugar-binding subsites in glycosyl hydrolases [1], Biochem. J. 321 (1997) 557-559, https://doi.org/ 10.1042/bj3210557.

[49] S.J. Charnock, T.D. Spurway, H. Xie, M.H. Beylott, R. Virden, R.A.J. Warren, G. P. Hazlewood, H.J. Gilbert, The topology of the substrate binding clefts of glycosyl hydrolase family 10 xylanases are not conserved, J. Biol. Chem. 273 (1999) 32187-32199, https://doi.org/10.1074/jbc.273.48.32187.

[50] A. Ezer, E. Matalon, S. Jindou, I. Borovok, N. Atamna, Z. Yu, M. Morrison, E. A. Bayer, R. Lamed, Cell surface enzyme attachment is mediated by family 37 carbohydrate-binding modules, unique to Ruminococcus albus, J. Bacteriol. 190 (2008) 8220-8222, https://doi.org/10.1128/JB.00609-08.

[51] H. Ohara, S. Karita, T. Kimura, K. Sakka, K. Ohmiya, Characterization of the Cellulolytic Complex (Cellulosome) from Ruminococcu, Biosci. Biotechnol. Biochem. 64 (2000) 254-260, https://doi.org/10.1271/bbb.64.254.

[52] M. Morrison, J. Miron, Adhesion to cellulose by Ruminococcus albus : a combination of cellulosomes and Pil-proteins? FEMS Microbiol. Lett. 185 (2000) 109-115, https://doi.org/10.1111/j.1574-6968.2000.tb09047.x.

[53] R.M. Kappes, B. Kempf, S. Kneip, J. Boch, J. Gade, J. Meier-Wagner, E. Bremer, Two evolutionarily closely related $\mathrm{ABC}$ transporters mediate the uptake of choline for synthesis of the osmoprotectant glycine betaine in Bacillus subtilis, Mol. Microbiol. 32 (1999) 203-216, https://doi.org/10.1046/j.1365-2958.1999.01354. $\mathrm{x}$.

[54] A. Maqbool, R.S.P. Horler, A. Muller, A.J. Wilkinson, K.S. Wilson, G.H. Thomas, The substrate-binding protein in bacterial ABC transporters: dissecting roles in the evolution of substrate specificity, Biochem. Soc. Trans. 43 (2015) 1011-1017, https://doi.org/10.1042/BST20150135.

[55] Y. Du, W.W. Shi, Y.X. He, Y.H. Yang, C.Z. Zhou, Y. Chen, Structures of the substrate-binding protein provide insights into the multiple compatible solute binding specificities of the Bacillus subtilis ABC transporter OpuC, Biochem. J. 436 (2011) 283-289, https://doi.org/10.1042/BJ20102097.

[56] E.A. Bayer, J.-P. Belaich, Y. Shoham, R. Lamed, The Cellulosomes: Multienzyme Machines for Degradation of Plant Cell Wall Polysaccharides, Annu. Rev. Microbiol. 58 (2004) 521-554, https://doi.org/10.1146/annurev. micro.57.030502.091022.

[57] P. Bule, V.M. Pires, C.M. Fontes, V.D. Alves, Cellulosome assembly: paradigms are meant to be broken!, Curr. Opin. Struct. Biol. 49 (2018) 154-161, https://doi.org/ 10.1016/j.sbi.2018.03.012.

[58] C.M.G.A. Fontes, H.J. Gilbert, Cellulosomes: Highly Efficient Nanomachines Designed to Deconstruct Plant Cell Wall Complex Carbohydrates, Annu. Rev. Biochem. 79 (2010) 655-681, https://doi.org/10.1146/annurev-biochem-091208085603.

[59] M.R. Christopherson, J.A. Dawson, D.M. Stevenson, A.C. Cunningham, S. Bramhacharya, P.J. Weimer, C. Kendziorski, G. Suen, Unique aspects of fiber degradation by the ruminal ethanologen Ruminococcus albus 7 revealed by physiological and transcriptomic analysis, BMC Genomics 15 (2014) 1066, https:// doi.org/10.1186/1471-2164-15-1066.

[60] P.J. Weimer, N.P.J. Price, O. Kroukamp, L.M. Joubert, G.M. Wolfaardt, W.H. Van Zyl, Studies of the extracellular glycocalyx of the anaerobic cellulolytic bacterium Ruminococcus albus 7, Appl. Environ. Microbiol. 72 (2006) 7559-7566, https:// doi.org/10.1128/AEM.01632-06.

[61] R.S. Pegden, M.A. Larson, R.J. Grant, M. Morrison, Adherence of the gram-positive bacterium Ruminococcus albus to cellulose and identification of a novel form of cellulose-binding protein which belongs to the Pil family of proteins, J. Bacteriol. 180 (1998) 5921-5927, https://doi.org/10.1128/jb.180.22.5921-5927.1998.

[62] S.E. Ryu, Structural mechanism of disulphide bond-mediated redox switches, J. Biochem. 151 (2012) 579-588, https://doi.org/10.1093/jb/mvs046.

[63] V. Gupta, K.S. Carroll, Sulfenic acid chemistry, detection and cellular lifetime, Biochim. Biophys. Acta - Gen. Subj. 1840 (2014) 847-875, https://doi.org/ 10.1016/j.bbagen.2013.05.040.

[64] L.B. Poole, The basics of thiols and cysteines in redox biology and chemistry, Free Radic, Biol. Med. 80 (2015) 148-157, https://doi.org/10.1016/j. freeradbiomed.2014.11.013.

[65] Y. Huang, J.P. Marden, C. Julien, C. Bayourthe, Redox potential: an intrinsic parameter of the rumen environment, J. Anim. Physiol. Anim. Nutr. (Berl). 102 (2018) 393-402, https://doi.org/10.1111/jpn.12855.

[66] C. Julien, J.-P. Marden, C. Moncoulon, Bayourthe, Redox Potential Measurement a New Way to Explore Ruminal Metabolism, (93)2010, ADSA/ASAS Jt. Annu. Meet. Denver, Color, USA, 2010, 2010-07-11-2010-07-15,.

[67] C. Julien, J.P. Marden, C. Bonnefont, R. Moncoulon, E. Auclair, V. Monteils, C. Bayourthe, Effects of varying proportions of concentrates on ruminal-reducing power and bacterial community structure in dry dairy cows fed hay-based diets, Animal. 4 (2010) 1641-1646, https://doi.org/10.1017/S1751731110000972.

[68] V. Aurilia, J.C. Martin, K.P. Scott, D.K. Mercer, M.E.A. Johnston, H.J. Flint, Organisation and variable incidence of genes concerned with the utilization of xylans in the rumen cellulolytic bacterium Ruminococcus flavefaciens, Anaerobe 6 (2000) 333-340, https://doi.org/10.1006/anae.2000.0358. 